\title{
Determine the structure of phosphorylated modification of icariin and its antiviral activity against duck hepatitis virus $\mathrm{A}$
}

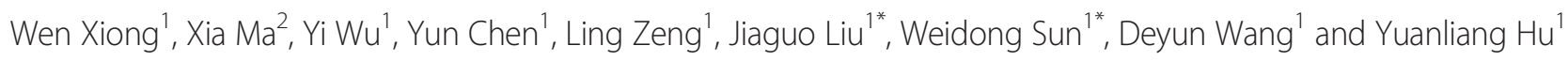

\begin{abstract}
Background: Our previous research showed that icariin (1) and its phosphorylated structural modification (2) improved the survival and attenuated oxidative stress and liver dysfunction induced by duck virus hepatitis. In this paper, we were one step closer to determine the structure of phosphorylation icariin (2) by the FT-IR, HRESIMS and ${ }^{13} \mathrm{C} N M R$. Anti-DHAV activities of 1 and 2 were compared in duck embryonic hepatocytes (DEHs) cultured in vitro and by artificial infection method in vivo. Additionally, the antiviral mechanisms of replication/release in vitro and the DHAV gene expression in vivo of 1 and 2 were analyzed.
\end{abstract}

Results: Compound 2's molecular formula was $\mathrm{C}_{33} \mathrm{H}_{42} \mathrm{O}_{18} \mathrm{P}$. The results indicated that 1 and 2 effectively resisted DHAV invading DEHs, that they decreased the mortality of ducklings challenged with DHAV, and that 2 performed more effectively. 1 and 2 performed evenly on DHAV release; however, 2 restrained virus replication far more effectively. Since the anti-DHAV mechanisms of 1 and 2 in vitro probably involve suppression of replication and release, 2's better performance in anti-DHAV may result from its far more effectively inhibiting virus replication.

Conclusions: The compound 2's chemical structure was defined as 8-prenylkaempferol-4'-methylether-3-rhamnosyl-7(6"'-phosphate)-glycoside. 1 and 2 exhibited anti-virus activity on DHAV. Our results suggest that 1 and 2 might become an anti-virus plant material candidate.

Keywords: Icariin, Phosphorylated structural modification, HRESIMS, NMR, Duck hepatitis virus A

\section{Background}

Duck viral hepatitis (DVH) is an acute, contagious, highly fatal disease of young ducklings, which was first described on Long Island, NY, USA, in 1949 [1]. The causative agent, duck hepatitis virus (DHV), historically belongs to the family Picornaviridae and is divided into three serotypes (DHV-1, 2, and 3). DHV-1 is the most widely distributed and the most virulent one among the three types of DHV [2]. Recently, sequence analysis of duck hepatitis virus type 1 led to its classification as the only member of a new genus, Avihepatovirus, of the family Picornaviridae, so the DHV-1 was renamed to DHAV [3]. DHAV predominantly infects young ducklings aged less than three weeks. Clinically, the disease is

\footnotetext{
* Correspondence: liujiaguo@njau.edu.cn; swd100@njau.edu.cn ${ }^{1}$ Institute of Traditional Chinese Veterinary Medicine, College of Veterinary Medicine, Nanjing Agricultural University, Nanjing 210095, People's Republic of China

Full list of author information is available at the end of the article
}

acute, rapidly spreading, with a shorter course and high mortality rate. Meanwhile, the DVH is an attractive research model of human hepatitis, with great potentialities in both human and veterinary medicine [4]. In the absence of effective anti-DHAV drugs, immunizing ducks or young ducklings with attenuated DHAV vaccines is the primary approach to disease control. However, vaccines are not totally effective and any clinical manifestation may cause potentially irreparable damage.

Several types of flavonoids including those from epimedium and propolis as well as prescriptions of flavonoids ingredients showed significant resistance to Newcastle disease, infectious bursal disease and other viral diseases in our previous experiments [5], although the underlying mechanisms were not researched in detail. Epimedium is a well-known traditional herbal medicine in China used for centuries to invigorate kidney and strengthen kidney yang. Contemporary pharmacologic experiments indicate that Epimedium flavone has anti-aging, anti-tumor and 
anti-osteoporosis activities [6-9]. Icariin $\left(\mathrm{C}_{33} \mathrm{H}_{40} \mathrm{O}_{15}, \mathbf{1}\right.$, Fig. 1.) is the main effective component of Epimedium brevicornum Maxim [10]. 1 exhibits many biological activities and pharmacological effects, including antioxidant, antiinflammatory, anti-tumor [11]. Previous research showed that 1 enhanced the cellular and humoral immunity in mice, and increased the phagocytic activity of macrophages in immune-depression mouse models caused by massive doses of hydrocortisone and hydroxycarbamide [12]. Therefore, we choose the $\mathbf{1}$ as the study object.

Molecular modification of flavonoids and polysaccharide became an important research field along with the increasing pursuit about manifold biological activities of modified. Many studies confirmed that the biological activities of the Chinese herbal ingredients could be improved by the chemical method (sulfated, phosphated, selenylation). In our previous published work, we found that the compound $\mathbf{1}$ and phosphorylated icariin $\left(\mathrm{C}_{33} \mathrm{H}_{42} \mathrm{O}_{18} \mathrm{P}\right.$, 2, Fig. 1) could alleviate the oxidative stress and liver injury in ducklings caused by DHAV. These outcomes were better in ducklings treated with 2 than in those treated by $\mathbf{1}$. In clinical trials, compared with 1, 2 could significantly improve survival rate [13]. This is the most important to the meaning of the actual production application. So we believe that this novel structure resulted in the difference. But between the $\mathbf{1}$ and $\mathbf{2}$, their antioxidant effect was similar. It's suggested that there may be another resistance mechanisms to anti-DHAV infection. To further study its resistance mechanism, we hold the opinion that it is essential to confirm the structure of $\mathbf{2}$ and study the effect of drug for viral multiplication process. Above on, we determined the chemical structure of 2 by the FT-IR, HRESIMS and ${ }^{13} \mathrm{C}$ NMR and the compound $\mathbf{1}$ and compound $\mathbf{2}$ antiviral efficacies against DHAV in vivo and in vitro were investigated.

\section{Methods}

\section{Reagents and virus}

Dulbecco's modified eagle medium (DMEM) (Gibco) supplemented with streptomycin $100 \mathrm{IU} / \mathrm{mL}$, penicillin $100 \mathrm{IU} / \mathrm{mL}, 10 \%$ fetal bovine serum and glutamine $0.75 \mathrm{mg} / \mathrm{mL}$ was used as the nutritive medium. The fetal bovine concentration of the maintain medium (MM) was reduced to $1 \%$. Dulbecco's Hanks Balanced Salt Solution (D-Hank's) was used for washing the embryo. The $\mathrm{pH}$ of D-Hank's, DMEM and MM solutions was adjusted to 7.4 with $5.6 \% \mathrm{NaHCO}_{3}$ and stored at $4{ }^{\circ} \mathrm{C}$. Trypsin (Amresco) was dissolved with D-Hank's up to $0.2 \%$. The 3-(4,5-dimethylthiazol-2-yl)-2,5-diphenyltetrazolium bromide (MTT, Amresco) was dissolved to $5 \mathrm{mg} /$ $\mathrm{mL}$ with phosphate-buffered saline (PBS), filtered through a $0.22 \mu \mathrm{m}$ syringe filter, and stored at $4{ }^{\circ} \mathrm{C}$ in dark bottles. Other chemicals used in the experiment were analytical grade. RNAiso Plus Reagent (Lot no. 9108), PrimeScript RT Master Mix Kit (Lot no. RR036A) and SYBR Premix Ex Taq (Tli RNaseH Plus) Kit (Lot no. RR036A) were bought from Takara. Fluorescein isothiocyanate-labeled rabbit antiDHAV (Lot no. orb8860) was bought from biorbyt. DHAV $\left(\mathrm{LD}_{50}: 5 \times 10^{-3}\right)$ strain $L Q_{2}$ used in the challenge experiments was supplied by the Shandong Institute of Poultry (Shandong, China, $-70{ }^{\circ} \mathrm{C}$ storage). All other chemicals are from standard commercial suppliers, having analytical grade quality.

\section{Preparation of icariin}

Compound 1 was purified repeatedly from the extract of Epimedium segittatum by column chromatography (CC) and prepared HPLC. The dried leaves $(5 \mathrm{~kg})$ of this plant were extracted three times with $85 \%(\mathrm{v} / \mathrm{v}) \mathrm{EtOH}$ under refluxed (40 L each time for $2 \mathrm{~h}$ ). The combined extract was concentrated under reduced pressure to give a residue $(0.3 \mathrm{~kg})$, which was further partitioned with petroleum ether (PE, boiling point $60-90{ }^{\circ} \mathrm{C}, 4 \mathrm{~L}$ ), ethyl acetate (EtOAc, $4 \mathrm{~L}$ ) and $n-\mathrm{BuOH}(4 \mathrm{~L})$, successively. The EtOAc fraction (38 g) was subjected to a silica gel CC (400 g, 100-200 mesh, $600 \times 40 \mathrm{~mm}$ ) eluted with a step gradient of $\mathrm{CH}_{2} \mathrm{Cl}_{2}-\mathrm{MeOH}-\mathrm{H}_{2} \mathrm{O}$ (90:1:0.1, 40:1:0.1, 20:1:0.1, 10:1:0.1, 5:1:0.1, v/v, $3 \mathrm{~L}$ each step gradient) to give five sub-fractions (E1-E5, $2.2 \mathrm{~g}, 3.1 \mathrm{~g}, 3.8 \mathrm{~g}, 4.6 \mathrm{~g}$, $8.9 \mathrm{~g}$, respectively). E4 $(0.2 \mathrm{~g})$ was then purified by Sephadex LH-20 CC $(1200 \times 24 \mathrm{~mm})$ with $\mathrm{MeOH}-\mathrm{H}_{2} \mathrm{O}$ ( $2: 1$ to $1: 1, \mathrm{v} / \mathrm{v}, 1.2 \mathrm{~L}$ each gradient) to obtain crude flavonoids $(0.12 \mathrm{~g})$. The crude flavonoids were further separated by prepared HPLC (column Kromasil $250 \times 10 \mathrm{~mm}$, $\left.5 \mu \mathrm{m}, \mathrm{CH}_{3} \mathrm{CN}-\mathrm{H}_{2} \mathrm{O}, 23: 77, \mathrm{v} / \mathrm{v}, 1.6 \mathrm{~L}\right)$ and recrystallized

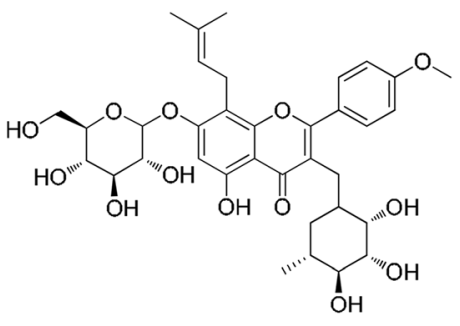

1

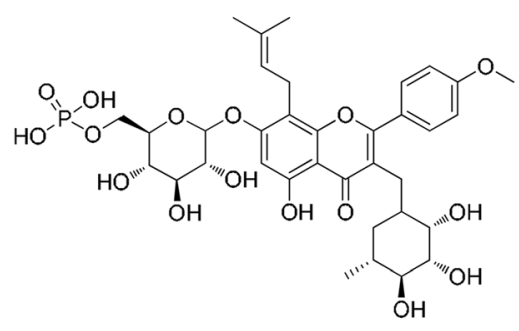

2

Fig. 1 Structure of icariin (1) and 6"'-phosphate icariin (2) 
with water repeatedly to yield Icariin $(83 \mathrm{mg})$, whose purity quotient was over $98 \%$.

HPLC conditions: YMC-Triart C18, $(5 \mu \mathrm{m}, 4.6 \times 250 \mathrm{~mm}$; YMC), solvent system: A - MeOH, B- $\mathrm{H}_{2} \mathrm{O}, \mathrm{C}-\mathrm{MeCN}, \mathrm{D}-$ $0.2 \% \mathrm{H}_{3} \mathrm{PO}_{4}$; flow rate: $1 \mathrm{~mL} / \mathrm{min}$; injection volume: $20 \mu \mathrm{L}$; Sample concentration: $10 \mathrm{mg} / \mathrm{mL}$ in $\mathrm{MeOH}$. DAD conditions: $270 \mathrm{~nm}$.

HRESIMS conditions: positive ion mode; scan range: $500-4000 \mathrm{~m} / z$; source temperature: $300{ }^{\circ} \mathrm{C}$; ion spray voltage $4 \mathrm{kV}$.

\section{Preparation of phosphorylated icariin}

2.5 g sodium trimetaphosphate and 1.0 g sodium tripolyphosphate were mixed in $50 \mathrm{~mL}$ of distilled water, with stirring. Compound 1 ( $500 \mathrm{mg}$ ) was dissolved in $100 \mathrm{~mL}$ of distilled water and added to the sodium trimetaphosphatesodium tripolyphosphate reagent, and stirred in a water bath at $70{ }^{\circ} \mathrm{C}$ for $6 \mathrm{~h}$ at $\mathrm{pH}$ 9. The resulting solution was dialyzed, purified by ODS column chromatography and preparative HPLC (YMC, $4 \mu \mathrm{m}, 150 \mathrm{~mm} \times 20 \mathrm{~mm}, \mathrm{MeCN} /$ $\left.\mathrm{H}_{2} \mathrm{O}, 35: 65\right)$, UV detection at $210 \mathrm{~nm}$, and lyophilized to yield compound 2 .

Icariin (1): yellow amorphous powder; FT-IR $(\mathrm{KBr})$ $v_{\text {max }}: 3396,1651,1600,1500,1453 \mathrm{~cm}^{-1} ;{ }^{13} \mathrm{C}$ NMR (DMSO-d $\mathrm{d}_{6}$, $100 \mathrm{MHz}$ ) data in Table 1; HRESIMS $\mathrm{m} / \mathrm{z} 676.7400$ $[\mathrm{M}+\mathrm{H}]^{+}$(calcd for $\left.\mathrm{C}_{33} \mathrm{H}_{41} \mathrm{O}_{15}, 677.2396\right)$.

Phosphorylated icariin (2): yellow amorphous powder; FT-IR(KBr) $v_{\text {max }}: 3384,1652,1610,1430,1504,1148,919 \mathrm{~cm}^{-1}$; ${ }^{13} \mathrm{C}$ NMR (DMSO- $\mathrm{d}_{6}, 100 \mathrm{MHz}$ ) data in Table 1; HRESIMS $m / z$ 757.2034 $[\mathrm{M}+\mathrm{H}]^{+}$(calcd for $\left.\mathrm{C}_{33} \mathrm{H}_{42} \mathrm{O}_{18} \mathrm{P}, 757.2072\right)$.

\section{Animal experiments}

Animal experiments conformed to the Guide for the Care and Use of Laboratory Animals published by the US National Institutes of Health (NIH Publication, Eighth edition, 2011) and were approved by the Nanjing Agricultural University Animal Care Committee (No. 20130093, 2013). To ameliorate suffering, animals which were not expected to survive were humanely euthanized. All steps were complied with AVMA Guidelines for the Euthanasia of Animals (2013 Edition).

One-day-old cherry valley ducks were purchased from Nanjing Tangquan Poultry Farm (Nanjing, China). Ducks were housed in wire cages $(60 \mathrm{~cm} \times 100 \mathrm{~cm})$ in air conditioned rooms at $37{ }^{\circ} \mathrm{C}$ with lights on for $24 \mathrm{~h}$ before the study. The temperature was gradually reduced to room temperature and 12-h light/12-h dark phases, which were kept constant for the remainder of the study. Ducks were fed a commercial starter diet provided by the feed factory of Jiangsu Academy of Agricultural Science (Nanjing, China). Three-day-old cherry valley ducks $(\mathrm{n}=180)$ were randomly divided into four groups: 1-treated group, 2-treated group, virus control $(\mathrm{VC})$ group, and a blank control $(\mathrm{BC})$ group (separately reared). Ducklings allocated to the $\mathbf{1}, \mathbf{2}$ and $\mathrm{VC}$
Table $1{ }^{13} \mathrm{C}$ NMR $(100 \mathrm{MHz})$ data of Compounds $1-2^{\text {a }}$

\begin{tabular}{|c|c|c|}
\hline & $1^{b}$ & $2^{b}$ \\
\hline position & $\delta_{C,}$ type & $\delta_{C, t y p e}$ \\
\hline 2 & $157.80, C$ & $157.79, C$ \\
\hline 3 & $135.11, C$ & $135.12, \mathrm{C}$ \\
\hline 4 & $178.77, \mathrm{C}$ & $178.77, \mathrm{C}$ \\
\hline 5 & $160.98, C$ & $160.99, C$ \\
\hline 6 & $98.59, \mathrm{CH}$ & $98.60, \mathrm{CH}$ \\
\hline 7 & $161.88, C$ & $161.89, \mathrm{C}$ \\
\hline 8 & 108.77,C & $108.78, C$ \\
\hline 9 & $153.48, C$ & $153.49, \mathrm{C}$ \\
\hline 10 & $106.06, C$ & $106.07, \mathrm{C}$ \\
\hline 11 & $21.89, \mathrm{CH}_{2}$ & $21.90, \mathrm{CH}_{2}$ \\
\hline 12 & $122.60, \mathrm{CH}$ & $122.61, \mathrm{CH}$ \\
\hline 13 & $131.58, \mathrm{C}$ & $131.58, \mathrm{C}$ \\
\hline 14 & $25.94, \mathrm{CH}_{3}$ & $25.93, \mathrm{CH}_{3}$ \\
\hline 15 & $18.33, \mathrm{CH}_{3}$ & $18.33, \mathrm{CH}_{3}$ \\
\hline $1^{\prime}$ & $122.73, \mathrm{C}$ & $122.74, \mathrm{C}$ \\
\hline $2^{\prime}, 6^{\prime}$ & $131.04, \mathrm{CH}$ & $131.04, \mathrm{CH}$ \\
\hline $3^{\prime}, 5^{\prime}$ & $114.55, \mathrm{CH}$ & $114.56, \mathrm{CH}$ \\
\hline $4^{\prime}$ & $159.56, \mathrm{C}$ & $159.56, C$ \\
\hline $1 "$ & 102.46,CH & $102.46, \mathrm{CH}$ \\
\hline $2^{\prime \prime}$ & $70.12, \mathrm{CH}$ & $70.13, \mathrm{CH}$ \\
\hline $3^{\prime \prime}$ & $70.55, \mathrm{CH}$ & $70.55, \mathrm{CH}$ \\
\hline $4 "$ & $71.18, \mathrm{CH}$ & $71.17, \mathrm{CH}$ \\
\hline $5^{\prime \prime}$ & $70.78, \mathrm{CH}$ & $70.79, \mathrm{CH}$ \\
\hline $6^{\prime \prime}$ & $17.93, \mathrm{CH}_{3}$ & $17.93, \mathrm{CH}_{3}$ \\
\hline $1 " '$ & $101.01, \mathrm{CH}$ & $101.01, \mathrm{CH}$ \\
\hline $2^{\prime \prime \prime}$ & $73.83, \mathrm{CH}$ & $73.84, \mathrm{CH}$ \\
\hline $3^{\prime \prime \prime}$ & $77.07, \mathrm{CH}$ & $77.08, \mathrm{CH}$ \\
\hline $44^{\prime \prime \prime}$ & $71.58, \mathrm{CH}$ & $71.85, \mathrm{CH}$ \\
\hline $5^{\prime \prime \prime}$ & $77.66, \mathrm{CH}$ & $77.67, \mathrm{CH}$ \\
\hline 6"' & $61.10, \mathrm{CH}_{2}$ & $70.17, \mathrm{CH}_{2}$ \\
\hline $\mathrm{OCH}_{3}$ & $55.98, \mathrm{CH}_{3}$ & $55.99, \mathrm{CH}_{3}$ \\
\hline
\end{tabular}

${ }^{\mathrm{a}}$ The chemical shifts $(\delta)$ are expressed in parts per million. ${ }^{\mathrm{b}}$ Data recorded in dimethyl sulfoxide- $\mathrm{d}_{6}$

groups were intramuscularly injected with $0.2 \mathrm{~mL}$ of DHAV $\left(20 \times \mathrm{LD}_{50}\right)$ per duckling. Ducklings allocated to the $\mathbf{1}$ or $\mathbf{2}$ groups were given aqueous $\mathbf{1}$ or $\mathbf{2}$ at the dosage of $31.25 \mathrm{mg} / \mathrm{Kg}$ (net concentration) of per duckling, SID, for 3 days starting on the same day as DHAV injection. Before used, 1 was prepared with $3 \%$ ethanol dissolved, and added a co-solvent $0.5 \%$ Tween 80 . In order to ensure the consistency of test, we added the equal amount of ethanol and Tween 80 in the drinking in the 2, VC and $\mathrm{BC}$ groups. The dissolution characteristic of $\mathbf{2}$ is instant into the water. Blood samples were taken from five ducklings in each group at the $4^{\text {th }} \mathrm{h}$, the $8^{\text {th }} \mathrm{h}$, and 
the $54^{\text {th }} \mathrm{h}$ after injecting DHAV. Half of each blood sample was treated with heparin for anticoagulation and the remainder was left to coagulate. Number of ducks which had been taken blood samples needed to eliminate $(n=15$ per group).

\section{Preparation of duck embryonic hepatocytes (DEHs) and DHAV}

Livers were removed from 14-to-16-day-old duck embryos in sterile conditions followed by gallbladder evisceration [14]. The livers were washed three times with D-Hank's. The tissue was minced with eye scissors and washed three times with D-Hank's. Liver tissue was digested with a solution of $0.2 \%$ trypsin at $37{ }^{\circ} \mathrm{C}$ for 4 to $6 \mathrm{~min}$. As soon as the trypsin was completely absorbed, the tissue was rinsed three times with D-Hank's and an appropriate amount of DMEM growth medium was added. The seeding cell density was controlled within the range of $0.8 \times 10^{6}-1.2 \times 10^{6}$ cell/mL, incubated at $37{ }^{\circ} \mathrm{C}$ in a humid atmosphere of $5 \%$ $\mathrm{CO}_{2}$, the growth medium replaced after 24 h [15]. DMEM was removed when the duck embryo hepatocytes grew into monolayer. The duck embryonic hepatocytes monolayer (DEHs) was washed with calcium and magnesium-free phosphate-buffered saline (CMF-PBS, $\mathrm{pH}$ 7.4) once, and left as standby until CMF-PBS was removed again. The DHAV used for challenge experiments and antiviral assays was supplied by the Shandong Institute of Poultry in China and proliferated by inoculating DEHs. The $\mathrm{TCID}_{50}$ of the virus liquid was $1 \times 10^{-3}$ by Reed-Muench assay [16]. It was diluted into $5 \times 10^{-2}\left(50 \mathrm{TCID}_{50}\right)$ with $\mathrm{MM}$ and used for antiviral assays.

\section{Antiviral activity in vitro}

The maximum safe concentration of 1 was $250 \mu \mathrm{g} / \mathrm{mL}$ tested by preliminary experiment with MTT method while that of 2 was $1250 \mu \mathrm{g} / \mathrm{mL}$. 1 was serially twofold diluted with $\mathrm{MM}$ from $250 \mu \mathrm{g} / \mathrm{mL}$ to $31.25 \mu \mathrm{g} / \mathrm{mL}$, and 2 from $1250 \mu \mathrm{g} / \mathrm{mL}$ to $156.25 \mu \mathrm{g} / \mathrm{mL}$, thus obtaining 4 concentrations each. $70 \mu \mathrm{L}$ DHAV was added to each well of 96-well culture plate containing the DEHs monolayer. Meanwhile, cell control (CC) group and virus control (VC) group were set. The plate was cultured at $37{ }^{\circ} \mathrm{C}$ in a humid atmosphere of $5 \% \mathrm{CO}_{2}$ for $2 \mathrm{~h}$. The virus solution was removed and the monolayer was washed three times with DHank's. Subsequently, $70 \mu \mathrm{L}$ dilution of test ingredient was added to test well using 5 wells per concentration. The plate was left at $37{ }^{\circ} \mathrm{C}$ in a humid atmosphere of $5 \%$ $\mathrm{CO}_{2}$. As the $\mathrm{VC}$ group showed significantly cytopathic effect (approximately after $72 \mathrm{~h}$ ), the MTT method was used to determine the DEHs activity [17]. The $A_{570}$ value and virus inhibitory rate $\left[\left(\overline{\mathrm{A}}_{\text {drug+virus }}-\overline{\mathrm{A}}_{\text {virus control }}\right) /\left(\overline{\mathrm{A}}_{\text {cell }}\right.\right.$ control $\left.-\overline{\mathrm{A}}_{\text {virus control }}\right) \times 100 \%$ ] were considered as the indicators of antiviral activity in vitro [18].

\section{Quantitative analysis of blood DHAV}

To monitor the blood virus contents in virusemia phases (the $4^{\text {th }} \mathrm{h}$ and the $8^{\text {th }} \mathrm{h}$ ) and stable (the $54^{\text {th }} \mathrm{h}$ ) phases of the disease, blood samples randomly taken from 5 feathers per group at the $4^{\text {th }} \mathrm{h}$, the $8^{\text {th }} \mathrm{h}$ and the $54^{\text {th }} \mathrm{h}$ after challenged with virus were collected, treated with heparin anticoagulation and used for testing its virus nucleic acid contents. Real-time polymerase chain reaction (Real-time PCR) was employed in the quantitative analysis of DHAV gene expression at the $4^{\text {th }} \mathrm{h}$, the $8^{\text {th }} \mathrm{h}$ and the $54^{\text {th }} \mathrm{h}$ in vivo [19].

\section{Clinical effect}

Mortality was calculated after all the young ducklings ceased to die using the equation: Mortality of each group $(\%)=$ Death in each group/effective samples in each group $\times 100 \%$, and the number of ducks providing blood samples needed to be eliminated (15 feathers per group).

\section{Analysis of virus replication}

$400 \mu \mathrm{L}$ DHAV was added into the 24-well culture plate containing a DEHs monolayer, while the $\mathrm{CC}$ and $\mathrm{VC}$ wells were reserved. The plate was incubated at $37{ }^{\circ} \mathrm{C}$ for $2 \mathrm{~h}$ in a humid atmosphere of $5 \% \mathrm{CO}_{2}$, and the virus solution removed. The plate was washed 3 times with D-Hank's. Later, $400 \mu \mathrm{L}$ dilution of test drug was added into the test wells, three wells in parallel, as the most effective antiviral concentration. The 24-well culture plate was incubated at $37{ }^{\circ} \mathrm{C}$ for $24 \mathrm{~h}$ in a humid atmosphere of $5 \% \mathrm{CO}_{2}$ and the total RNA was extracted. Real-time PCR was used to analyze the extent of virus replication.

\section{Analysis of virus release}

$400 \mu \mathrm{L}$ DHAV was added into the 24-well culture plate containing monolayer DEHS, while the $\mathrm{CC}$ and $\mathrm{VC}$ wells were reserved. The plate was incubated at $37{ }^{\circ} \mathrm{C}$ for $2 \mathrm{~h}$ in a humid atmosphere of $5 \% \mathrm{CO}_{2}$. The virus solution was removed and the plate was washed 3 times with D-Hank's. $400 \mu \mathrm{L}$ dilution of test drug at the most effective antiviral concentration was then added into the test wells, three wells in parallel. The plate was continuously incubated at $37{ }^{\circ} \mathrm{C}$ in a humid atmosphere of $5 \%$ $\mathrm{CO}_{2}$ for $48 \mathrm{~h}$. The supernatant of cells was centrifuged and the sediment was removed. $100 \mu \mathrm{L}$ supernatant and $100 \mu \mathrm{L}$ DEHs $\left(0.8 \times 10^{6}-1.2 \times 10^{6}\right.$ cells $/ \mathrm{mL}$, as the internal reference) were mixed together and the total RNA was extracted. Finally real-time PCR was used to analyze the virus release content.

\section{Primer design}

The primers based on the complete genome of DHAV (ZJ strain; Genbank: EU841005) were designed using Primer Premier Software (version 5.0). The forward and reverse primers were 5'-GCCACCCTTCCTGAGTTTGT-3' 
(positions: 3336-3355) and 5'-TACCATTCCACTTCTCC TGCTT-3' (positions: 3489-3510), respectively. Duck Betaactin was selected as the control. The primers based on the complete coding sequence of Anasplatyrhynchos beta-actin mRNA (Genbank: EF667345) were designed using Primer Software (version 5.0). The forward and reverse primers were 5'-CTTTCTTGGGTATGGAGTCCTG-3' (positions: 826-847) and 5'-TGATTTTCATCGTGCTGGGT-3' (positions: 995-1014), respectively.

\section{Statistical analysis}

$2^{-\Delta \Delta C T}$ method was used to analyze relative gene expression data [20]. The data of $A_{570}$ value and relative gene expression value were expressed as the mean \pm S.D. Duncan's multiple range tests were used to analyze the difference among groups with the software SPSS 20.0. $\chi^{2}$-test was used to analyze the difference between the mortality. Significant differences were considered as $p<0.05$.

\section{Results}

Compound 1 was obtained as a yellow, amorphous powder. Its molecular formula $\left(\mathrm{C}_{33} \mathrm{H}_{40} \mathrm{O}_{15}\right)$ was established on the basis of high-resolution electrospray ionization mass spectrometry (HRESIMS) $\left(\mathrm{m} / z 676.7400[\mathrm{M}+\mathrm{H}]^{+}\right.$; calcd for $\mathrm{C}_{33} \mathrm{H}_{41} \mathrm{O}_{15}, 677.2396$, Fig. 2) in combination with ${ }^{13} \mathrm{C}$ nuclearmagnetic resonance (NMR) data (Table 1). The FT-IR spectrum exhibited characteristic absorptions for hydroxy $\left(3396 \mathrm{~cm}^{-1}\right)$, carbonyl $\left(1651 \mathrm{~cm}^{-1}\right)$, and aromatic (1600 and $\left.1454 \mathrm{~cm}^{-1}\right)$ functionalities. It was consistent with the structure of icariin [21].

Compound 2 was obtained as a yellow, amorphous powder. Its molecular formula $\left(\mathrm{C}_{33} \mathrm{H}_{42} \mathrm{O}_{18} \mathrm{P}\right)$ was established on the basis of ${ }^{13} \mathrm{C}$ NMR and HRESIMS data $(\mathrm{m} / \mathrm{z}$ 757.2034 $[\mathrm{M}+\mathrm{H}]^{+}$; calcd for $\mathrm{C}_{33} \mathrm{H}_{42} \mathrm{O}_{18} \mathrm{P}$, 757.2072, Fig. 2). The FT-IR spectrum exhibited characteristic absorptions for hydroxy $\left(3384 \mathrm{~cm}^{-1}\right)$, carbonyl $\left(1652 \mathrm{~cm}^{-1}\right)$, and aromatic (1610 and $1430 \mathrm{~cm}^{-1}$ ) functionalities, it was similar to 1 . Furthermore, 2 also displayed extra absorption peaks at 1160.61 and $918.15 \mathrm{~cm}^{-1}$, corresponding to the phosphate group. The ${ }^{13} \mathrm{C}$ NMR data (Table 1 ) of 2 were similar to those of 1 , except for the the C-6"' $\left(1 \mathrm{C}-6^{\prime \prime}: \delta_{\mathrm{C}} 61.10\right.$; $\left.2 \mathrm{C}-6^{\prime \prime}: \delta_{\mathrm{C}} 70.17\right)$, it suggested that the phosphate group was located at C-6"', which instead of oxhydryl. Combined with FT-IR, HRESIMS and ${ }^{13} \mathrm{C}$ NMR data, suggesting that compound $\mathbf{2}$ was also a phosphorylated derivative of $\mathbf{1}$ and the structure was defined as 8-prenylkaempferol-4' methylether-3-rhamnosyl-7- (6"'-phosphate)-glycoside and given the name 6"'-phosphate icariin.

Table 2 listed the $A_{570}$ values and virus inhibitory rate in the anti-DHAV activity test in DEHs. The $\mathrm{A}_{570}$ values of the 1 group ranging from $62.5 \mu \mathrm{g} / \mathrm{mL}$ to $31.25 \mu \mathrm{g} /$ $\mathrm{mL}$, and the $\mathrm{A}_{570}$ values of the 2 group ranging from $312.5 \mu \mathrm{g} / \mathrm{mL}$ to $156.25 \mu \mathrm{g} / \mathrm{mL}$ were significantly higher than that of the $\mathrm{VC}$ group. The $\mathrm{A}_{570}$ value of the 2 at
$156.25 \mu \mathrm{g} / \mathrm{mL}$ was also notably higher than that of the CC group, which indicated that 2 also promote cell growth. The virus inhibitory rates of $\mathbf{2}$ were higher than that of 1 at similar concentrations, with the highest one at $135.78 \%$, while the highest of $\mathbf{1}$ being $98.28 \%$.

The mortality of young ducklings in the $\mathrm{BC}, \mathrm{VC}, 1,2$ groups was $0,30,24,21$ feathers. All ducklings in the $\mathrm{BC}$ group survived. After treatment with $\mathbf{1}$ and $\mathbf{2}$, the young ducklings challenged with DHAV no longer died after $72 \mathrm{~h}$, while all of the ducklings in the VC group died on the 4th day. Both mortality of compound $\mathbf{1}$ (80\%) and compound 2 (70\%) were lower than that of the $\mathrm{VC}$ group (100\%), and compound 2 group's mortality was significantly lower than that of the VC group.

A quantitative analysis of the DHAV gene expression in blood at the 4th, the 8th and the 54th $\mathrm{h}$ after injected with virus was illustrated in Fig. 3. No DHAV gene expression was found in the BC group. DHAV gene expression of the $\mathrm{VC}$ group in the 4th $\mathrm{h}$ after injected virus was set to 1 and that of the $\mathrm{BC}$ group was set to 0 . The $\mathrm{VC}$ group dynamics indicated that the DHAV content first increased and then decreased in vivo of ducklings, with the pattern of the $\mathbf{1}$ and $\mathbf{2}$ groups similar to that of the $\mathrm{VC}$ group. The relative expressions of DHAV gene in blood of the $\mathbf{1}$ and $\mathbf{2}$ groups were lower than that of the VC group during the same period. Four hours after DHAV injection, the virus gene expressions in both the $\mathbf{1}$ and $\mathbf{2}$ groups were lower than that of the VC group. At the 8th hour after DHAV injection the virus contents of the $\mathbf{1}$ and $\mathbf{2}$ groups were lower than that of the VC group with significant difference. At the 54th $\mathrm{h}$ after DHAV injection the virus gene content of the 2 group was remarkably lower than that of the $\mathrm{VC}$ group.

The effect of $\mathbf{1}$ and $\mathbf{2}$ on replication of DHAV was illustrated in Fig. 4. No DHAV gene expression was found in the CC group. DHAV gene expression of the VC group in the twenty-fourth hour was set to 1 . Relative DHAV gene expressions of $\mathbf{1}$ and $\mathbf{2}$ groups were 0.549 and 0.248 ; both were significantly lower than that of the $\mathrm{VC}$ group. Relative expression of $\mathbf{2}$ was significantly lower than that of $\mathbf{1}$.

The effect of $\mathbf{1}$ and $\mathbf{2}$ on the release of DHAV was illustrated in Fig. 5. No DHAV gene expression was found in the CC group. The DHAV gene expression of the $\mathrm{VC}$ group in the $48 \mathrm{~h}$ was set to 1 and that of the $\mathrm{BC}$ group was set to 0 . Relative expressions of $\mathbf{1}$ and $\mathbf{2}$ were 0.476 and 0.575 . And both were significantly lower than that of the $\mathrm{VC}$ group.

\section{Discussion}

Acid ions cannot only bind to virus or cell skin cation to inhibit viral invasion or replication, but also enhance the antiviral effect and water solubility of drugs [22]. This experiment sought for the optimal conditions for 


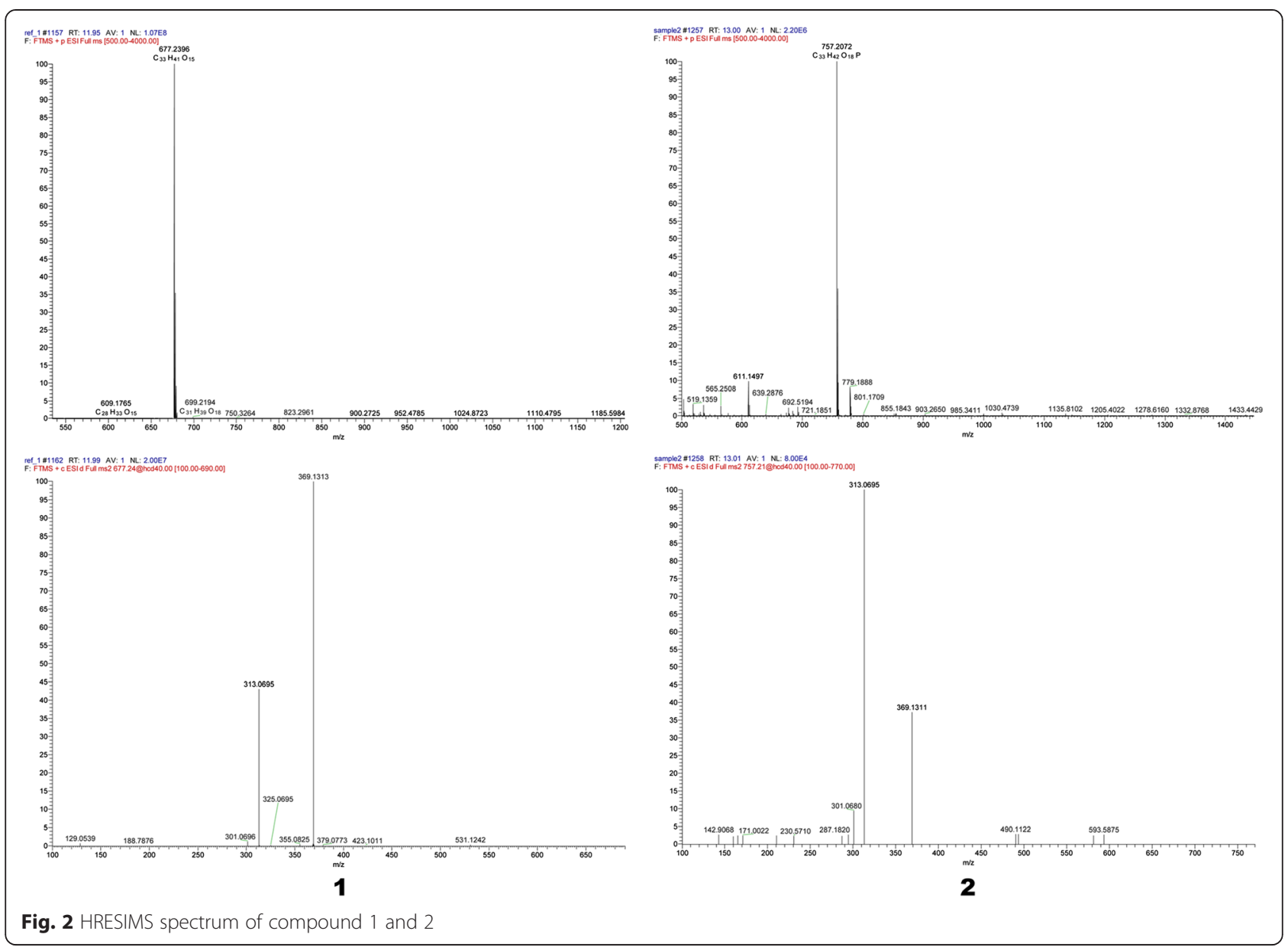

phosphorylated modification of $\mathbf{1}$ and successfully introduced phosphate group. It still preserved the flavones' basic chemical structure. The results showed that $\mathbf{2}$ had significantly better water solubility than $\mathbf{1}$ and was suitable for practical application. The higher the drug's maximum concentration was, the safer it was inside the cell in vitro [23]. In the present experiment, the maximum tolerable dose of $2(1250 \mu \mathrm{g} / \mathrm{mL})$ was much higher than that of $\mathbf{1}(250 \mu \mathrm{g} / \mathrm{mL})$. The results indicated that the cellular toxicity of $\mathbf{1}$ may be significantly reduced by phosphorylation.

The antiviral activity assays of $\mathbf{1}$ and $\mathbf{2}$ in vitro using MTT method indicated that higher $\mathrm{A}_{570}$ values were associated with improved antiviral properties [24]. Virus inhibitory rates directly reflected the drug's antiviral performance. Within a certain range, the $\mathrm{A}_{570}$ values of $\mathbf{1}$ and 2 were significantly higher than that of the $\mathrm{VC}$ group; with some $A_{570}$ values of 2 even higher than the

Table $2 A_{570}$ values and virus inhibitory rate in DHAV test on DEHs

\begin{tabular}{|c|c|c|c|c|c|c|c|}
\hline Group & Concentration $^{\mathrm{A}}(\mu \mathrm{g} / \mathrm{mL})$ & $A_{570}$ & Virus inhibitory rate(\%) & Group & Concentration $^{\mathrm{A}}(\mu \mathrm{g} / \mathrm{mL})$ & $A_{570}$ & Virus inhibitory rate(\%) \\
\hline \multirow[t]{4}{*}{1} & 250 & $0.191 \pm 0.026^{c}$ & 1.72 & 2 & 1250 & $0.241 \pm 0.026^{c}$ & 0.92 \\
\hline & 125 & $0.211 \pm 0.032^{b c}$ & 18.97 & & 625 & $0.261 \pm 0.010^{c}$ & 19.27 \\
\hline & 62.5 & $0.230 \pm 0.016^{b}$ & 35.34 & & 312.5 & $0.365 \pm 0.032^{\mathrm{ab}}$ & 114.68 \\
\hline & 31.25 & $0.303 \pm 0.013^{\mathrm{a}}$ & 98.28 & & 156.25 & $0.388 \pm 0.020^{\mathrm{a}}$ & 135.78 \\
\hline VC & & $0.189 \pm 0.018^{c}$ & & VC & & $0.240 \pm 0.014^{c}$ & \\
\hline $\mathrm{CC}$ & & $0.305 \pm 0.006^{a}$ & & CC & & $0.349 \pm 0.024^{b}$ & \\
\hline
\end{tabular}

Data within a column without the same superscripts $(a-c)$ differ significantly $(p<0.05)$

${ }^{\mathrm{ab}}$ With ${ }^{\mathrm{a}}$ and ${ }^{\mathrm{b}}$ were no significant differences. ${ }^{\mathrm{bc}}$ With ${ }^{\mathrm{b}}$ and ${ }^{\mathrm{c}}$ were no significant differences

${ }^{\text {A }}$ The safe concentration determined by prior cytotoxicity tests 


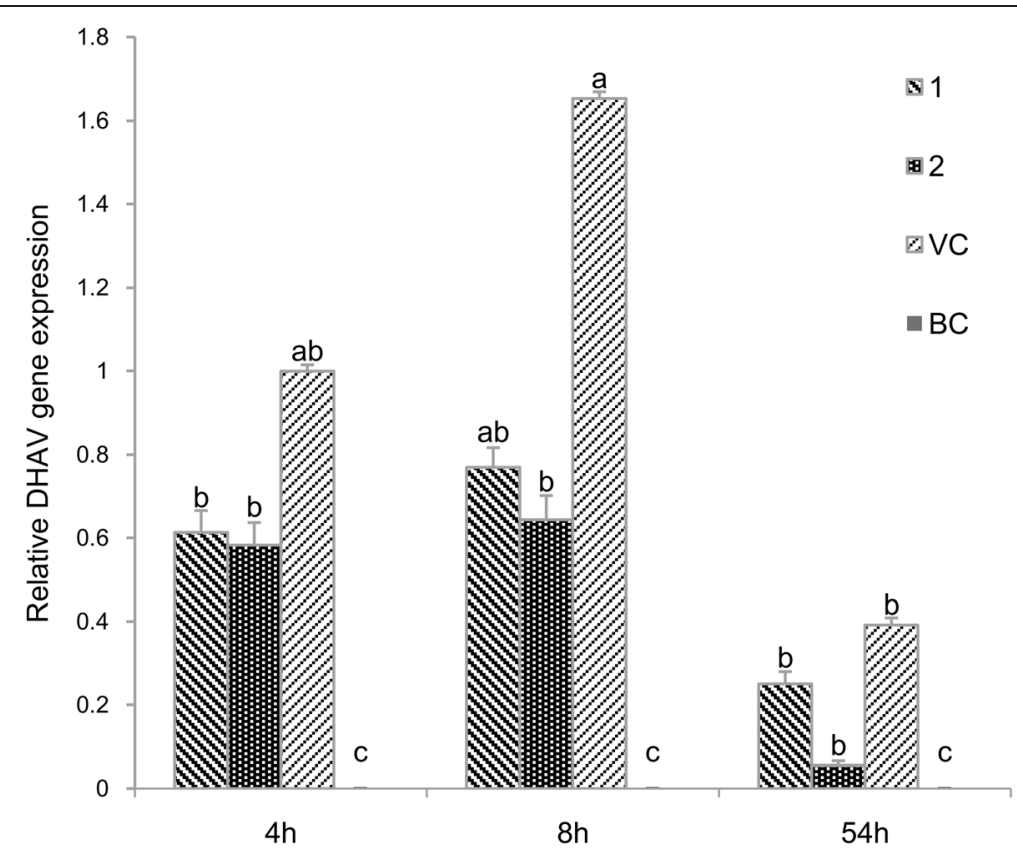

Fig. 3 Quantitative analysis of the DHAV gene expression in blood at the 4 th, the 8 th and the 54 th $h$ after injected virus. DHAV gene expression of the VC group at $4 \mathrm{~h}$ after injected virus was set to 1 and that of the BC group was set to 0 . The different letters on a column differ significantly $(p<0.05)$

CC group. Within the effective concentration range, the virus inhibitory rates of $\mathbf{2}$ and the maximum inhibitory rate were both higher than those of $\mathbf{1}$. The results suggested that both $\mathbf{2}$ and $\mathbf{1}$ in vitro possessed strong anti-DHAV function, with $\mathbf{2}$ stronger than $\mathbf{1}$.

In clinical trials, DHAV was infectious for young ducklings aged up to 3 weeks, particularly those less than 1week-old, whose mortality rate was higher than $90 \%$ [25]. Therefore, we selected 3-day-old young ducklings for this experiment taking into account the clinical significance. In this study, all ducklings in the BC group survived. After treatment with $\mathbf{1}$ and $\mathbf{2}$, the young ducklings challenged with DHAV no longer died after $72 \mathrm{~h}$, while all of the ducklings in the VC group died on the 4th day. Mortalities of the $\mathbf{1}$ and $\mathbf{2}$ groups were both lower than that of the VC group, which proved that both $\mathbf{1}$ and $\mathbf{2}$ had anti-DHV effect. If focused on the mortality of the $\mathbf{2}$ group, we could

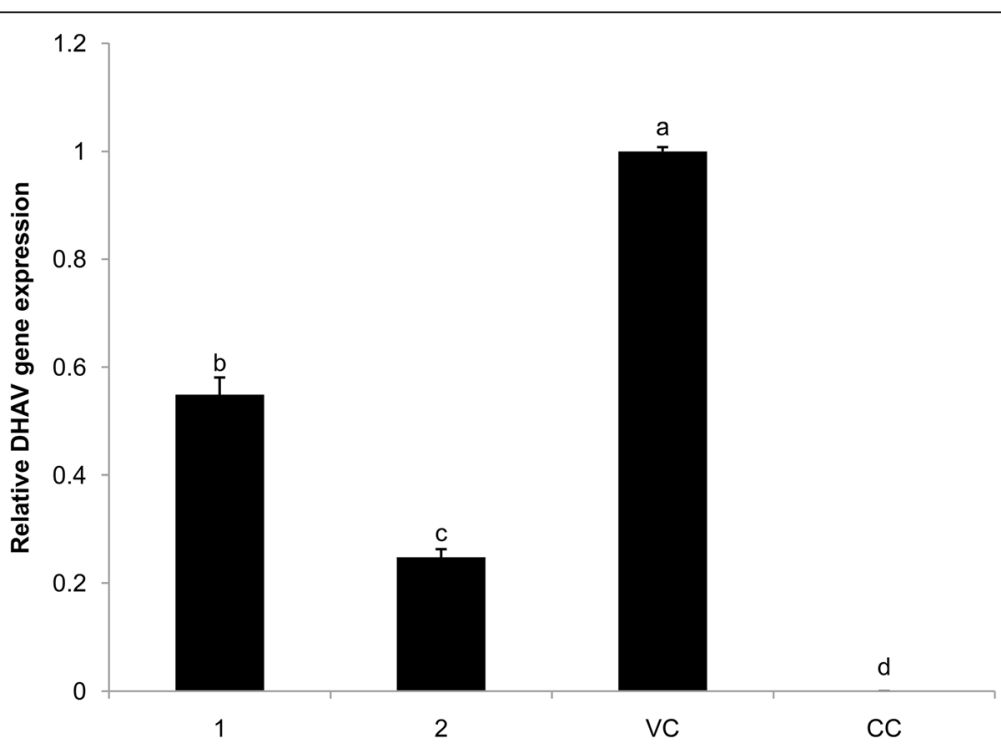

Fig. 4 Replication DHAV gene expression in DEHs. Effect of $\mathbf{1}$ and $\mathbf{2}$ on DHAV replication. DHAV gene expression of the VC group was set to 1 and that of the BC group was set to 0 . The different letters on a column differ significantly $(p<0.05)$ 


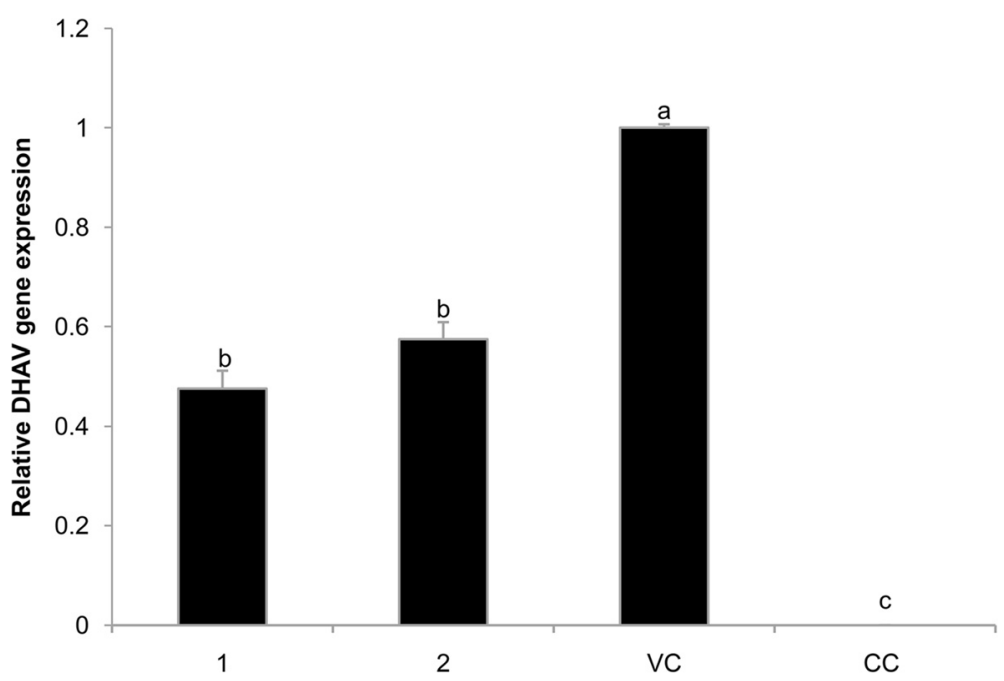

Fig. 5 Release DHAV gene expression in DEHs. Effect of $\mathbf{1}$ and $\mathbf{2}$ on DHAV release. DHAV gene expression of the VC group was set to 1 and that of the $\mathrm{BC}$ group was set to 0 . The different letters on a column differ significantly $(p<0.05)$

find that it was significantly lower than that of the $\mathrm{VC}$ group, indicating its superior effect compared to $\mathbf{1}$. The results were consistent with the anti-DHAV invading cells, in vitro.

DHAV is classified in the family parvoviridae [26]. It completes a cycle of replication in $6-8 \mathrm{~h}$, in vivo. In early phase of infection, humoral immunity to antiDHAV is still not active. Instead, organisms mainly relied on the direct antivirus effects of the drug. A quantitative analysis of the DHAV gene expression in blood at the 4th, the 8th and the $54^{\text {th }} \mathrm{h}$ after injected with virus was illustrated in Fig. 3. Four hours after virus invasion, it was possible that virus still failed to complete replication. As the gene expressions of DHAV in the $\mathbf{1}$ and $\mathbf{2}$ groups were lower than that of VC group, no substantial differences between virus level in blood of the 1, 2 and $\mathrm{VC}$ groups was observed. At the $8^{\text {th }} \mathrm{h}$, the virus had at least completed one replication cycle. The blood virus contents in the $\mathbf{1}$ and $\mathbf{2}$ groups were significantly lower than that of the $\mathrm{VC}$ group. In addition, since $\mathbf{2}$ was more potent, the 2 group blood virus content was lower than that of the $\mathbf{1}$ group. At the $54^{\text {th }} \mathrm{h}$, with the activation of humoral immunity and increased cytokine levels, the levels of the 1, 2 and VC groups' blood virus plummeted. The $\mathbf{1}$ and $\mathbf{2}$ groups' blood virus contents were lower than that of the VC group and this is especially significant for the $\mathbf{2}$ group. The results were consistent with the death of the ducklings in the challenging experiment. We are submitting another article has reported that the contents of IFN- $\gamma$, IL-2 and IL- 6 in the $\mathbf{1}$ and $\mathbf{2}$ groups were significantly higher than those in the $\mathrm{VC}$ group at the $54^{\mathrm{th}} \mathrm{h}$, which indicated that $\mathbf{1}$ and $\mathbf{2}$ could obviously improve immunomodulatory activity. It also demonstrated that the treatment of traditional
Chinese medicine maybe more reflected in the balance of the internal systems, rather than directly inhibited or killed pathogenic microorganisms.

Previous studies established a solid basis for the molecular detection of DHAV using Real-time PCR [19]. RT-PCR with its higher specificity, less PCR contamination and higher automation has been widely applied in the field of diagnosis and detection of DHAV. During virus replication, the relative quantitative gene expressions of the $\mathbf{1}$ and $\mathbf{2}$ groups were significantly lower than that of the VC group (Fig. 4). The results suggested that $\mathbf{1}$ and 2 greatly inhibited the replication of DEHs in vitro, and that $\mathbf{2}$ outperformed $\mathbf{1}$. Lu et al. [22] also found that acid ions prevented virus from replicating inside cells. Acid ions of $\mathrm{PO}_{4}^{3-}$ introduced into $\mathbf{1}$ enhanced the inhibition of DHAV in vitro.

In virus release phase (Fig. 5), the relative quantitative gene expressions of the $\mathbf{1}$ and $\mathbf{2}$ groups were significantly lower than that of the $\mathrm{VC}$ group. Both had similar inhibitory effect on DHAV releasing DEHs in vitro. Therefore, based on the results of virus replication and release in vitro, both $\mathbf{1}$ and $\mathbf{2}$ had significant inhibitory function on virus activity, although the $\mathbf{2}$ was better due to its acidic groups. Due to direct inhibition of virus replication in the $\mathbf{1}$ and $\mathbf{2}$ groups, and consequent lowered blood viral content, the ducks were spared from possible harm and showed a decreased Mortality, especially true for the $\mathbf{2}$ group. The antiviral immune response stimulated by the $\mathbf{1}$ and $\mathbf{2}$ also helped in substantially reducing the damage due to DHAV. Additional studies to confirm our findings in vivo are required.

\section{Supporting information}

${ }^{13} \mathrm{C}$ NMR of compound 1 and compound 2. 


\section{Conclusion}

The compound $\mathbf{2}$ was also a phosphorylated derivative of $\mathbf{1}$ and the structure was defined by FT-IR, HRESIMS and ${ }^{13} \mathrm{C}$ NMR. Compound $\mathbf{1}$ and $\mathbf{2}$ effectively resisted DHAV from invading DEHs in vitro, and had good therapeutic effects in young ducklings infected with DHAV. The Mortality was significantly decreased and $\mathbf{2}$ showed better effect than 1, it showed that the novel structure was worth further research for application. The mechanism underlying the antiviral activity of $\mathbf{2}$ and 1 in vitro was probably mediated by interference with the replication and release of virus. Due to the greater inhibition on virus replication than 1, 2 showed better antiviral effect.

\section{Competing interests}

The authors declare that they have no competing interests.

\section{Authors' contributions}

WX wrote the manuscript and performed the experiments. WX XM YW YC LZ DW YH conceived the study, and participated in its design and coordination. JL WS designed the experiments, supervised the laboratory work and critically revised the manuscript. All authors read and approved the final draft of the manuscript.

\section{Acknowledgements}

This work was supported by the National Natural Science Foundation of China (Grant No. 31172355), Project Funds from the Priority Academic Program Development of Jiangsu Higher Education Institutions (PAPD), and Special Funds for Agro-scientific Research of Public Interest (201303040 and 201403051). We are grateful to all of the staff at the Institute of Traditional Chinese Veterinary Medicine of Nanjing Agricultural University for helping conduct the experiments.

\section{Author details}

'Institute of Traditional Chinese Veterinary Medicine, College of Veterinary Medicine, Nanjing Agricultural University, Nanjing 210095, People's Republic of China. ${ }^{2}$ Pharmaceutical Engineering Department, Henan University of Animal Husbandry and Economy, Zhengzhou 450011, People's Republic of China.

Received: 4 June 2015 Accepted: 25 June 2015

Published online: 14 August 2015

\section{References}

1. Levine PP, Fabricant J. A hitherto-undescribed virus disease of ducks in North America. Cornell Vet. 1950;40:71-86.

2. Woolcock PR. Diseases of Poultry. lowa: lowa State Press; 2003. p. 343-54.

3. Pan M, Yang X, Zhou L, Ge X, Guo X, Liu J, et al. Duck Hepatitis A Virus Possesses a Distinct Type IV Internal Ribosome Entry Site Element of Picornavirus. J Virol. 2012:86(2):1129-44.

4. Reaiche GY, Le Mire MF, Mason WS, Jilbert AR. The persistence in the liver of residual duck hepatitis B virus covalently closed circular DNA is not dependent upon new viral DNA synthesis. Virology. 2010:406(2):286-92.

5. Zhang YQ, Sun ZA, Liu JG, Wang DY, Zhang BK, Yi F, et al. Flavone ingredients can synergistically inhibit NDV infecting cell and improve ND vaccine's protective rate. Int J Biol Macromol. 2012;51(3):201-8.

6. Havsteen $\mathrm{BH}$. The biochemistry and medical significance of the flavonoids. Pharmacol Ther. 2002;96(2-3):67-202.

7. Kong XF, Hu YL, Rui R, Wang DY, Li XG. Effects of Chinese herbal medicinal ingredients on peripheral lymphocyte proliferation and serum antibody titer after vaccination in chicken. Int Immunopharmacol. 2004;4(7):975-82.

8. H-f L, X-y G, Yang W-z, K-d L, Ye M, Sun C, et al. Antioxidant flavonoids from Epimedium wushanense. Fitoterapia. 2012;83(1):44-8.

9. Zhang DW, Cheng Y, Wang NL, Zhang JC, Yang MS, Yao XS. Effects of total flavonoids and flavonol glycosides from Epimedium koreanum Nakai on the proliferation and differentiation of primary osteoblasts. Phytomedicine. 2008;15(1-2):55-61.
10. Wu H, Lien EJ, Lien LL. Chemical and pharmacological investigations of Epimedium species: a survey. Progress in drug research Fortschritte der Arzneimittelforschung Progres des recherches pharmaceutiques. 2003:60:1-57.

11. Wang $Y$, Dong $H$, Zhu M, Ou Y, Zhang J, Luo H, et al. Icariin exterts negative effects on human gastric cancer cell invasion and migration by vasodilator-stimulated phosphoprotein via Rac1 pathway. Eur J Pharmacol. 2010;635(1-3):40-8.

12. Sun $Y$, Wang J, Luo Y. Effects of total flavones from Epimedium $L$. on IL-2 and NK activity in immunodepressant mice. Chinese Traditional and Herbal Drugs. 2002;7:635-6.

13. Xiong W, Chen Y, Wang Y, Liu JG. Roles of the antioxidant properties of icariin and its phosphorylated derivative in the protection against duck virus hepatitis. BMC Vet Res. 2014;10:9.

14. Sauerbrei A, Schacke M, Schultz U, Egerer R, Merkle I, Glebe D, et al. Alternative methods for validation of cell culture infection with duck hepatitis B virus. J Virol Methods. 2005;129(2):178-85.

15. Schacke $M$, Glueck $B$, Wutzler $P$, Sauerbrei A. In vitro cultivation and cryopreservation of duck embryonic hepatocytes. J Virol Methods. 2009;157(1):25-31

16. Biacchesi S, Skiadopoulos MH, Yang LJ, Murphy BR, Collins PL, Buchholz UJ. Rapid human metapneumovirus microneutralization assay based on green fluorescent protein expression. J Virol Methods. 2005;128(1-2):192-7.

17. Kaneko H, Fujiwara T, Mori S, Shigeta S. Evaluation of antiviral agents for adenovirus using the MTT method in vitro. Nippon Ganka Gakkai Zasshi. 2000;104(11):786-91.

18. Takeuchi H, Baba M, Shigeta S. An application of tetrazolium (MTT) colorimetric assay for the screening of anti-herpes simplex virus compounds. J Virol Methods. 1991;33(1-2):61-71.

19. Yang $M$, Cheng $A$, Wang $M$, Xing $H$. Development and application of a one-step real-time Taqman RT-PCR assay for detection of Duck hepatitis virus type1. J Virol Methods. 2008;153(1):55-60.

20. Livak KJ, Schmittgen TD. Analysis of relative gene expression data using real-time quantitative PCR and the $2(T)$ (-Delta Delta C) method. Methods. 2001;25(4):402-8

21. Xia Q, Xu D, Huang Z, Liu J, Wang X, Wang X, et al. Preparation of icariside II from icariin by enzymatic hydrolysis method. Fitoterapia. 2010:81(5):437-42.

22. Lu $Y$, Wang $D$, Hu $Y$, Huang $X$, Wang J. Sulfated modification of epimedium polysaccharide and effects of the modifiers on cellular infectivity of IBDV. Carbohydr Polym. 2008;71(2):180-6.

23. Verma A, Prasad KN, Singh AK, Nyati KK, Gupta RK, Paliwal VK. Evaluation of the MTT lymphocyte proliferation assay for the diagnosis of neurocysticercosis. J Microbiol Methods. 2010;81(2):175-8.

24. Huang X, Wang D, Hu Y, Lu Y, Guo Z, Kong X, et al. Effect of sulfated astragalus polysaccharide on cellular infectivity of infectious bursal disease virus. Int J Biol Macromol. 2008;42(2):166-71.

25. Tseng C-H, Knowles NJ, Tsai H-J. Molecular analysis of duck hepatitis virus type 1 indicates that it should be assigned to a new genus. Virus Res. 2007;123(2):190-203.

26. Kim M-C, Kwon Y-K, Joh S-J, Lindberg AM, Kwon J-H, Kim J-H, et al. Molecular analysis of duck hepatitis virus type 1 reveals a novel lineage close to the genus Parechovirus in the family Picornaviridae. J Gen Virol. 2006:87:3307-16.

\section{Submit your next manuscript to BioMed Central and take full advantage of:}

- Convenient online submission

- Thorough peer review

- No space constraints or color figure charges

- Immediate publication on acceptance

- Inclusion in PubMed, CAS, Scopus and Google Scholar

- Research which is freely available for redistribution 